\title{
Effect of Firm Structure on Corporate Cash Holding (Evidence from Non-Financial Companies)
}

\author{
Sher Khan ${ }^{*}$, Zhuangzhuang Peng ${ }^{1}$, Sohail Ahmad ${ }^{2}$, \\ Shahid Mahmood ${ }^{2}$, Ijaz Ahmad ${ }^{3}$ \\ ${ }^{1}$ School of Economics, Henan University, Kaifeng, China \\ ${ }^{2}$ College of Management, Shenzhen University, Shenzhen, China \\ ${ }^{3}$ Institute of Business and Management Sciences, The University of Agriculture, Peshawar, Pakistan \\ Email: *Sherkhan4477@gmail.com
}

How to cite this paper: Khan, S., Peng, Z. Z., Ahmad, S., Mahmood, S., \& Ahmad, I. (2019). Effect of Firm Structure on Corporate Cash Holding (Evidence from Non-Financial Companies). Journal of Financial Risk Management, 8, 1-14. https://doi.org/10.4236/jfrm.2019.81001

Received: January 7, 2019

Accepted: February 19, 2019

Published: February 22, 2019

Copyright $\odot 2019$ by author(s) and Scientific Research Publishing Inc. This work is licensed under the Creative Commons Attribution International License (CC BY 4.0).

http://creativecommons.org/licenses/by/4.0/

\begin{abstract}
The purpose of this study is to investigate the effect of firm structure (whether diversified or focused firms) on corporate cash holding. Samples of 80 non-financial companies were selected including diversified and focused firms which were listed on Karachi stock exchange for a period 7 years from 2006 to 2013. These diversified and focused firms were selected on the basis of equal proportionate method. Random effect model and descriptive statistics were used for the analysis of these variables. The results of these models showed that there is negative and significant effect of firm structure on corporate cash holding. We also find negative and significant relationship of leverage and Networking capital with the corporate cash holdings and the relation between growth opportunities and corporate cash holding was examined to be positive and significant. We also find a negative and insignificant relationship between firm size and corporate cash holding. The descriptive statistics showed that there was significant difference between the cash holding of diversified and focused firms. The diversified firms keep a smaller amount of cash as compare to the single segment companies (focused firms), which is in support of the trade-off theory. This paper contributes to current literatures with regard to organization structure (whether diversified or focused firms) on cash holding in a developing economy like Pakistan.
\end{abstract}

\section{Keywords}

Firm Structure, Corporate Cash Holding, Diversified or Focused Firms, Single and Multiple Segments Firms 


\section{Introduction}

Firms operating in the modern business world compared with the period of industrial revolution have been witnessing various challenges due to globalization, advancement in information and communication technologies, and privatization of industries among other factors. As a result, firms are continuously seeking ways to organize operational activities such as cash management in order to ensure optimal performance. The everyday exercises of the firm need the holding of certain amount of cash in order to exploit business opportunities and to diminish the expense of outer financing.

In today's business world, cash remains one of the most significant components of firm's assets. Numerous popular firms on the planet hold a considerable measure of their resources in the form of money, toward the end of 2002; the US non-financial and non-utility enterprises held $\$ 443$ billion in real money and money equivalents, of which all things considered speaks to around $21 \%$ percent of aggregate resources. Compared with the money offsets of around 10 percent of aggregate resources in 1988, the numbers have double in relative terms while different things, for example, obligation and speculation have stayed at a relative stable level over the same period. Having invigorated their monetary records with money in the course of recent years, numerous organizations now are confronting an issue of how to utilize the money productively. One of the key parts of corporate administration is to intelligently reinvest the money the business produces to improve benefits (Subramaniam et al., 2011).

Various studies have been conducted on the factors of corporate cash holding in developed countries. But this study examined the effect of organization structure (whether diversified or focused firms) on cash holding in a developing economy like Pakistan. However previous studies have mostly disregarded this aspect while analyzing cash holding of companies. Firms may be diversified firms or it may be focused. It is acknowledged in the literature of diversification that diversified companies are not only the grouping of segments. The growth opportunities of the different segments of the diversified firms may not be perfectly interrelated, which suggests that there is promising role for internal capital markets in these companies (Shin \& Stulz, 1998; Lamont, 1997; Khanna \& Tice, 2001), if the companies hold money for probable investment opportunities as in Opler et al. (1999) and responded to the underinvestment issue emerging from financing relate predation risk in not perfectly product market as in Haushalter et al. (2007) that the imperfect association which is mentioned above shows that the diversified companies need less cash at any one point in time to fulfill their investment needs. Also there is a flow of cash from one segment to the other which reduces the diversified firm's requirement of holding cash from the external capital market and it also reduces the advantages of holding money.

Further more diversified companies are capable of raising their fund by selling their assets than single segment companies. Shleifer and Vishney (1992) describe that the selling of asset can be good source of funding. Those firms which having 
more resources which can be effortlessly changed into money can increase their capital at low price by selling these assets. For that reason, the multi-segment firms are estimated to raise their money by selling of these assets, mainly the non-core units than single segment companies, which reduces the need for keeping money. At last multiple segment firms may face more agency problems that occur from the managers of segment, they will fight for the company's large resources (Rajan et al., 2000). So those segments which having more power will obtain more assets, which will go ahead to over-investment and other dead-weight expenses (Milgrom \& Roberts, 1990; Bagwell \& Zechner, 1993).

The corporate cash holding has an important role in the financial decision of the companies. The firm or economic institutions usually keep an optimal level of cash in order to avail any growth opportunities and projects with positive NPV (Opler et al., 1999). As per the literature various studies have been conducted on the determinants of cash holdings and it is proved that size, leverage, investment opportunities, net working capital, corporate governance have considerable consequences on cash holding but the effect of firm structure on cash holding is largely ignored by the researchers while analyzing cash holding of firms (Subramaniam et al., 2011). Thus, the current study focused whether the firm structure (whether diversified or focused) effect cash holding or not. The findings of this study will helpful for the diversified and focused firms to analyze and revise their capital structures and cash holdings level and improve it more. This study also examine to see the level of cash holding for both firms (diversified or focused firms) and our findings will help them to differentiate and know the differences. The findings of the this study is not only contribute to current literatures and the settlement of the still ongoing corporate cash holding debate, but could provide useful implications on the influence of firms structures on cash holding in selected industries of Pakistan. This study is helpful for policymakers and research scholars to examine the firm structure on corporate cash holding from different prospective such as by using adjusted Cash holding for different industries. We also contribute to scarce literature on the impact of firms structure on corporate cash holdings with regard diversified and focused firms. In Section 2, the theoretical literatures about theories related to our study and previous literature is presented. The methodology and descriptive statistic are presented in Section 3. Section 4 we presents the data analysis for of all models and findings. Section 5 concludes and recommendations.

\section{Theoretical and Previous Literature}

\subsection{Theoretical Background}

This part reviews the key opinions put forward in the literature on the company's essentials that can decide the corporate cash holdings. The theoretical models have various opinions as to how the examined company's essential factors influence cash holding decisions. 


\subsection{The Tradeoff Theory (TOT)}

The primary edition of tradeoff theory was perceived by Kraus and Litzenberger (1973) who measured a harmony between dead-weight expenses of insolvency and the tax reduction advantage of debt. Trade-off theory contends that companies set their ideal money property by considering the exchange off between the trivial benefits and the expenses included in holding such fluid resources. Ferreira and Vilela (2004) propose that there are three advantages for firms in holding money: 1) cash decreases the likelihood of financial trouble as it can serve as a preserve to manage unpredicted misfortunes and/or confinements to raise funds; 2) money property help to meet firms' speculation arrangements, given the requirements to raising trusts, and henceforth permit firms to put resources into their positive NPV ventures; 3 ) holding money minimizes the expenses of fund raising and liquidation expenses, if needed (Ferreira \& Vilela, 2004). Inside this theory, the impact of leverage on holding cash is vague. From one perspective, extremely leveraged companies are expected to face financial misery. This recommends that these firms hold money in order to decrease the chances of insolvency. Then again, if leverage is utilized as a list for the capacity to acquire obligation then the more utilized the firm is, minimizes the requirements for holding cash (Ferreira \& Vilela, 2004). The effect of growth opportunities on money holding is predicted to be positive by the tradeoff theory to reduce the cost of financial distress. It additionally demonstrates a negative connection between firm size and cash holding and short term resources can be effortlessly changed over into money and thus can be a substitute for networking capital. This proposes an inverse association of networking capital with money holding (Ozkan \& Ozkan, 2004).

\subsection{Pecking Order Theory}

This theory centered on the preliminary work of Myers (1984) in which it is stated that while funding their projects firms can follow a particular pattern. The firms first depend on the cheapest sources of financing, retained earnings, and when the first option exhausted then these firms use external sources. This theory states that when the investment needs are covered with the cash flows of the firm then it can repay its obligations, hold cash and also pay dividends. On the other hand, if the cash flows of the firms are insufficient then the firms decrease dividends, cash holdings and at last issues debt (Ferreira \& Vilela, 2004). This theory predicts a significant effect of leverage and profitability on the financial decisions of firms.

\section{Hypothesis of the Study}

$\mathrm{Ho}_{\mathbf{a}}$ : There is no significant effect of firm structure on corporate cash holding.

$\mathrm{H}_{\mathrm{a}}$ : There is a significant effect of firm structure on corporate cash holding.

$\mathrm{Ho}_{\mathrm{b}}$ : There is no significant difference between the effect of firm structure on corporate cash holding for diversified and focused firms.

$\mathrm{HI}_{\mathrm{b}}$ : There is significant difference between the effect of firm structure on 
corporate cash holdings for diversified and focused firms.

\subsection{Previous Literature}

The relationship of capital structure on performance of non-financial firms for Kanya was examined by (Mwangi et al., 2014) and found that financial leverage have negative effect on return on asset and return on equity. Al-Najjar and Clark (2017) examines the effect of in external and internal corporate governance's practices on holding cash for Middle East and North Africa countries. The results indicates that there is negative relationship between board size and cash holing and further explained that both types of governance practices are crucial as well as governance practices is important in cash holding decisions. Ozkan and Ozkan (2004) and Ferreira and Vilela (2004) examined the influencing factors of corporate cash holding in EMU nations. There consequences proposed that the investment chances and flow of cash can directly affect the keeping of money. The money holding is inversely affected by size, leverage, and liquidity of resources. It was also predicted by the study that association of cash property and Bank debt is also negative with money holding, which states that the good relation with financial institutions allows the firms to keep a smaller amount of money for protective reasons. Stowe and Xing (2006) explored the likelihood that the diversification discount is because of contrasting development opportunities in the middle of diversified and single-segment firms. They further discovered that there is a considerable decrease in the value of diversified companies notwithstanding when they control for the distinction in development chances among diversified and non-diversified companies Drobetz and Grüninger (2006) examined the causes of Cash holdings for a broad sample of 156 non-financial companies of Switzerland for a period from 1995 to 2004. The analysis of their study found that size of the company and assets solidity are both inversely associated to corporate money holdings. The association of working money flows and dividend outflows with cash reserves was expected to be positive. Additionally, Drobetz and Grüninger (2006) predicted a positive association between Chief Executive Officers duality and corporate money holdings, and a non-significant association between board size and money holdings. Another study conducted by Subramaniam et al. (2011) analyzed whether the organization structure (i.e. whether a company is multiple segment or single-segment) influences their money holdings. Utilizing Compustate company level and section level information, they found that multiple-segments companies keep altogether smaller amount of money as compared to their single-segment partners. Basil Al-Najjar (2011) examined the effect of dividend rule and capitals structure on cash holding in Russia, Brazil, China, and India and their consequences were compared with the UK and US sample. There results predicted an association between dividend policy and fund structure with corporate money holdings. They also found that influencing factors of cash holding showed resemblances in developed and developing countries. Results also pre- 
dicted that fund structure, firm size, and dividend plan, are important influences of cash holdings. Brisker et al. (2013) investigated the variation in corporate money holding procedure of S\&P 500 organizations from before to after their incorporation in the index. One year after incorporation, their mean industry-balanced cash holding decrease by about $32 \%$ from the prior year consideration. A few components clarify this decrease. The precautionary intention for money falls down because of these organizations getting to be more noticeable, less doubtful, and less inhabited to raise economical outside capital. Corporate administration declines after consideration because of expanded administrative entrenchment, which prompts a lessening in real money as proposed by the free cash flow theory. Most list firms face reducing growth opportunities and diminishing capital expenditures, which infers a lesser requirement for money possessions identified with the transaction intention.

\section{Methodology}

This study intends to investigate the effect of firm structure (whether diversified or focused firms) on corporate cash holding. Samples of 80 non-financial companies were selected including diversified and focused firms which were listed on Karachi stock exchange. The sample size of our study was restricted to 80 firms due to the non-availability of diversified firm's data. These diversified and focused firms were selected on the basis of equal proportionate method. Out of these 80 firms, 40 were diversified and 40 were focused firms. The financial companies were excluded from the study and the non-financial firm whose data was not available from 2006 to 2013 was also excluded. The selection of the period is based on the availability of the data. The panel data collected for this study was secondary in nature and the data related to the variables of the study was collected from the firm's annual reports and balance sheets analysis of the State Bank of Pakistan publications.

\subsection{Empirical Model and Variables Explanations}

\subsubsection{Variables Explanations}

This study intends to investigate the effect of firm structure (whether diversified or focused firms) on corporate cash holding. We use Cash holding as the main dependent variable which is calculated as the cash and cash correspondent divided by net assets, where net assets was measured as total assets minus cash and cash equivalents (Opler et al., 1999). Net assets are also called non cash assets. With this measure we can find out the ratio of how much firms have assets in cash. The main independent variable is firm structures. The firm structure (whether diversified or focused firm) is used as an independent variable. A dummy variable (diverse-dummy) is added for organization structure, where 1 is for diversified firm while 0 is for focused firms in the regressions model to predict the cash holdings of the firms. After that, we find out the effect of firm structure (whether diversified or focused firms) on cash holding and if any effect 
is found in cash holding then we will check that whether the influence of firm structure on cash holding is same or different for diversified and focused firms. The other control variable which affects our dependent variables is firm size. The larger firms are more diversified, the larger firms can finance their funds easily with low borrowing costs and are less likely to go insolvent, because they have easy entrance to the capital markets and banks (Ferreira \& Vilela, 2004; Opler et al., 1999). Therefore, an inverse association between Size of the firm and cash holding was predicted because of these reasons. The company's size can be calculated by using the natural logarithm of total assets of the firm (Opler et al., 1999). The other control variable is total leverage. The leverage of the firm can be calculated by using the book value of total liability divided by the book value total assets of the firm. The highly leverage firms need to hold more cash because of the higher chances of bankruptcy. But it was expected that cash levels decreases with high obligations (Baskin, 1987). Consequently, the leverage assets can be easily converted into cash and hence these high leverage companies hold less cash. A negative correlation between leverage and cash holding was expected (Opler et al., 1999; Ozkan \& Ozkan, 2004). Moreover, net working capital also affects our dependent variables. This is calculated by subtracting cash and cash equivalents from working capital which was further divided by book value of total assets (Ferreira \& Vilela, 2004). Another control variable is growth opportunities. The relation between growth opportunities and cash holding was expected to be positive because of the reason that those firms having more investment opportunities incur more cost in a cash deficiency due to the losses that take place from leaving important growth opportunities. Market to book ratio was used as a proxy for the growth opportunities of the companies, which was calculated by (Opler et al., 1999).

\subsubsection{Analytical Model}

The multiple regression models were used to examine the relationship between firm structure, firm size, leverage, $N W C$, Investment opportunities and cash holding of the companies. The model used firm structure, firm size, leverage, $N W C$ and Growth opportunities as independent variables of the study and cash holding as the dependent variable to find out the relationship between these variables.

$$
\begin{aligned}
\text { CASH }_{i t}= & \beta_{0}+\beta_{1}(\text { SZ })_{i t}+\beta_{2}(\text { lev })_{i t}+\beta_{3}(N W C)_{i t}+\beta_{4}(\text { MKTBook })_{i t} \\
& +\beta_{5}(\text { Divers }- \text { Dummy })_{i t}+\varepsilon_{i t}
\end{aligned}
$$

where;

$$
\begin{aligned}
& C A S H=\text { Cash holding; } \\
& S Z=\text { Firm Size; } \\
& \text { Lev = Leverage; } \\
& N W C=\text { Net Working Capital; } \\
& M K T B o o K=\text { Market to Book value; }
\end{aligned}
$$

Divers-Dummy $=$ is a diversify Dummy which is 1 for diversified firm and 0 
for focus firm.

Where $\beta_{0}$ and $\beta_{1}$ 's are the parameters of the model, $\beta_{0}$ is the intercept and $\beta$ is the slope. $\beta_{i}^{\prime}$ s are also called the regression coefficients. $\mathcal{E}$ is called the random error or residual term. The sign of $\beta_{\mathrm{i}}$ 's indicates the relationship (+ve or $-\mathrm{ve}$ ) between independent and dependent variables.

\section{Data Analysis and Discussions}

\subsection{Diagnostic Tests}

\subsubsection{Chow Test}

Chow test is basically used to differentiate between the Pooled OLS and Fixed Effect Model. It checks that which Model is best for the investigation of our data. Two hypotheses were generated to decide about the best model.

$\mathrm{H}_{0}$ : Pooled OLS is proper model for our data analysis.

$\mathrm{H}_{1}$ : Fixed Effect Model is proper model for our data analysis.

The results of Chow test from the table shows that $p$-value is 0.000 which is lower than 0.05 , so the alternative hypothesis of fixed effect model will be accept.

\subsubsection{Breusch-Pagan Lagrange Multiplier}

This test is used to decide among the Pooled Regression and Random Effect Model. So to decide between Pooled OLS and Random effect model null and alternative hypothesis were generated.

$\mathrm{H}_{0}$ : Pooled regression is appropriate for the analysis of our data.

$\mathrm{H}_{1}$ : Random Effect Model is appropriate for the analysis of our data.

The results of the Breusch-pagan in Table 1, shows that p-value $0.000<0.05$, so the alternative hypothesis will be accepted. This accepts Random effect model a suitable model for the examination of our data.

\subsubsection{Hausman Test}

Hausman Test was used to decide between the fixed effect Model and the Random effect model, to ensure that which model is the best for the current study data analysis. Null and alternative hypothesis were generated.

$\mathrm{H}_{0}$ : REM is satisfactory model for the analysis of our data.

$\mathrm{H}_{1}$ : FEM is satisfactory model for the analysis of our data.

The results of Hausman test in Table 1, shows that p-value is 0.495 which is greater than 0.05 , so the Null hypothesis of Random effect model will be accepted.

Table 1. Diagnostic tests for panel data model.

\begin{tabular}{ccccc}
\hline Test & Purpose & Test Statistics & p-value & Results \\
\hline Chow test & Pooled regression vs Fixed effect & F $(79,556)=4.416$ & 0.000 & Fixed effect model \\
Breusch-Pagan & Pooled regression vs Random effect model & Chi-square $(1)>191.391$ & 0.000 & Random effect model \\
Hausman test & Fixed effect model vs Random effect model & Chi-square $(4)>3.390$ & 0.495 & Random effect model \\
White's test & Presence of Heteroscedasticity & Chi-square $(19)>37.211$ & 0.007 & Presence of Heteroscedasticity \\
\hline
\end{tabular}




\subsubsection{White's Test}

We have run white's test on our data to find out the problem of heteroscedasticity in the data. Two hypotheses were generated to check the problem of Heteroscedasticity.

$\mathrm{H}_{0}$ : The problem of heteroscedasticity doesn't exist in the data.

$\mathrm{H}_{1}$ : There exists the problem of heteroscedasticity in the data.

Table 1 shows that the p-value of white's Test is 0.0075 , which is less than 0.05; the alternative hypothesis of existing Heteroscedasticity is accepted. There exists the problem of Heteroscedasticity in the data, to remove the problem of Heteroscedasticity; we have run Robust Standard error on the data.

The results of the Chow test recommend FE model for the Analysis of our data while the Breusch-pagan and Hausman test select RE Model. So the results show that RE is the suitable model for the Analysis of our data. The Results of RE model are given in Table 1.

\subsection{Random Effect Models}

The below given in Table 2, shows the results of Random Effect model. This model shows the effect of independent variables "Leverage, Size, Growth opportunities, Networking Capital and Firm structure" on the dependent variable "Cash Holding".

In Table 2, the value of R-square is 0.1794 , which means that the model predicts $17.94 \%$ percent variation in the value of dependent variable (cash holding) because of the independent variables (Leverage, Size, Growth opportunities, $N W C$ and firm structure). The value of F-statistic p-value is highly significant which indicate that model is fit and empirically analysis can be reliable.

Table 2 shows that the coefficient of leverage is $-0.092 \%$ which is highly significant and negatively effects cash holding. The negative sign of coefficient shows that there is an inverse relationship between leverage and corporate Cash holding, when leverage is increased then there will be decrease in the value of corporate Cash holding. This means if there is $1 \%$ increase in cash holding decreases the leverage by $-0.092 \%$. The result of the study suggests that there is -ive and significant effect of Leverage on Cash holding, which is similar to the

Table 2. Random effect model for the effect of firm structure on cash holding.

\begin{tabular}{ccccc}
\hline & Coefficient & Robust Std. Error & t-ratio & p-value \\
\hline Const & 0.211 & 0.095 & 2.226 & $0.026^{* *}$ \\
Leverage & -0.092 & 0.027 & -3.393 & $0.001^{* * *}$ \\
Size & -0.006 & 0.006 & -1.027 & 0.305 \\
MKTbook & 0.024 & 0.008 & 2.890 & $0.004^{* * *}$ \\
NWC & -0.051 & 0.025 & -2.028 & $0.042^{* *}$ \\
Divers dummy & -0.045 & 0.020 & -2.171 & $0.030^{* *}$ \\
\hline
\end{tabular}

Notes: This table presents the results of Random effect model. ${ }^{* * *},{ }^{* *}$ and ${ }^{\star}$ denote the statistical significance at levels of $1 \%, 5 \%$, and $10 \%$ respectively. $\mathrm{R}^{2}=0.1794$, F-ratio $=25.36$, p-value $=0.000$. 
results of Ferreira and Vilela (2004) high leveraged companies hold less money in order to avoid the expenditure of holding money.

Table 2 shows that the coefficient of Size is $-0.006 \%$. The value of coefficient shows per unit variation in explained variable because of the explanatory variable. So the results show that there is -0.006 change in cash holding when there is 1 unit of change in Size. The negative sign of coefficient shows that there is negative relation among size and Cash holding, when Size is increased then there will be decrease in the value of Cash holding. The result of the study shows that there is -ive and insignificant effect of size on Cash holding. The negative and insignificant association between cash holding and company's size is in support of the work of Kim et al. (1998), the negative association is also in support with the forecasting of trade-off theory which suggests size as an opposite substitute of information asymmetry. This means smaller companies have large information irregularity then larger companies. Companies think the smaller information irregularity as positive indication to financial institutions because information irregularity issue cause some extra borrowing restrictions which leads to expensive exterior financing (Kim et al., 1998). An inverse relationship between company size and corporate cash holding can be imagined because the larger companies can effortlessly increase their funds from capital Markets. This negative association is also reliable with the previous results of Pinkowitz and Williamson (2001), Ferreira and Vilela (2004) and Bates et al. (2009) which means firms with larger size hold less cash as compared to small firms.

The coefficient of investment opportunities is $0.024 \%$. The results show that there are $0.024 \%$ changes in cash holding when there is $1 \%$ change in Growth opportunities. The positive sign of coefficient shows that there is positive association between growth opportunities and money holding, when investment chances are increased then there will be increase in the value of Cash holding. The result of the study shows that there is positive and significant effect of investment opportunities on corporate Cash holding. The positive and significant effect of investment opportunities on corporate Cash holding is similar to the trade-off model of Ferreira and Vilela (2004), which states that companies with more growth opportunities hold more money to avoid monetary distress due to greater bankruptcy cost.

It is shown in Table 2, that the coefficient of Networking Capital is $-0.051 \%$. So the results reveal that there is $-0.051 \%$ change in cash holding when there is $1 \%$ of change in Networking Capital. The negative sign of coefficient shows that there exists a negative relationship between Networking Capital and Corporate cash holding, when Networking Capital is increased then there will be decrease in the amount of corporate Cash holding. The result of the study explains that there is negative and significant effect of Networking Capital on Money holding. The outcome of the study is supported by the work of Ferreira and Vilela (2004) and tradeoff theory, which states that Networking capital can be used as substitute of cash and can be easily converted into cash with low cost, so extra cash 
holding is not needed when there is more networking capital.

The result from Table 2 shows that the coefficient of Firm Structure is $-0.045 \%$. We used a dummy variable for the firm structure which is 1 for diversified firms and 0 for the non-diversified companies. So the results show that there are $-0.045 \%$ changes in cash holding when there is $1 \%$ of change in Firm Structure (diversified firms). The negative sign of coefficient shows that there is negative relationship among Firm Structure and Cash holding, when one more segment is added then there will be decrease in the amount of corporate Cash holding. The result of the study shows that there is negative and significant effect of Firm Structure on Cash holding, which is in support with the study of Subramaniam et al. (2011) that diversified companies' holds less money as compared to the focused firms, because the multiple segment firms have the accessibility to internal capital market and corresponding investment opportunities across the various divisions of diversified companies.

Table 3 shows the descriptive statistics of the data. To check the difference between the level of Cash holding of Diversified and Focused Firms, we used Independent Sample T-test. The independent sample T-test checks to find out significant difference between the means of the two samples. Here the T-test was used to differentiate between the various characteristics of the two groups. The results of the descriptive table show that the median (mean) cash holding for focused firms is $0.021(0.091)$ and that of diversified firms is $0.009(0.040)$. The results of Table 3 show that there is significant distinction between the cash holding of diversified and focused firms. The results show that diversified firms hold less Cash as compared to Focused firms. The focused and diversified firm also shows difference in other factors of corporate cash holdings. The T-test show a significant distinction in size between multiple segment and single segments firms because $\mathrm{p}$ value is less than 0.05 which shows that diversified firms are larger in size then the focused firms.

The results of Table 3 also show that there is significant difference between the Networking capital of diversified and focused firms. According to Opler et al. (1999) size and $N W C$ can be an important determinant of cash holding, the difference between these factors in multiple segments and single segment

Table 3. Independent sample T-Test for differentiating means of focused and diversified firms.

\begin{tabular}{|c|c|c|c|c|c|c|}
\hline \multirow{2}{*}{ Variable Names } & \multicolumn{2}{|c|}{ Focused Firms } & \multicolumn{2}{|c|}{ Diversified Firms } & \multirow{2}{*}{$\begin{array}{c}\text { T-State For } \\
\text { difference in } \\
\text { means }\end{array}$} & \multirow{2}{*}{ p-Value } \\
\hline & Means & Median & Mean & Median & & \\
\hline Cash holding & 0.091 & 0.021 & 0.040 & 0.009 & 0.051 & 0.000 \\
\hline Leverage & 0.642 & 0.594 & 0.586 & 0.632 & 0.055 & 0.056 \\
\hline Size & 14.917 & 14.888 & 15.874 & 15.895 & -0.956 & 0.000 \\
\hline MKTbook & 1.207 & 0.927 & 1.146 & 0.916 & 0.062 & 0.344 \\
\hline$N W C$ & -0.023 & -0.003 & 0.049 & 0.029 & -0.073 & 0.005 \\
\hline
\end{tabular}


companies can lead to different level of cash keeping. The results of the descriptive statistics are similar to that of Subramaniam et al. (2011).

\section{Conclusion and Recommendations}

This study was conducted to investigate the effect of firm structure on cash holding. It was concluded from the results of the study that there was found a significant and negative effect of firm structure on corporate cash holding. It was also concluded that the multiple segment companies keep low money as compared to single segment firms. The results of the study are in support of the work of Subramaniam et al. (2011), which argue that diversified firms hold less cash because there is an internal capital market, so when one segment need funds it can move freely from the other segment which can reduce the benefit of holding cash. He also argues that the other reason behind holding less cash for diversified firms is that they can raise their funds by selling noncore segment assets. Thus the marginal cost of keeping money is more for diversified firms, so diversified companies keep lower cash as compared to focused firms.

It is also concluded from the study that leverage has negative and significant effect on cash holding, which is similar to the work of trade-off model of (Ferreira \& Vilela, 2004), which states that leverage can be used as an alternate for money, so high leveraged companies hold less cash in order to avoid the cost of holding cash. The relation between size and cash holding was also found negative and insignificant. This is in support of the work of (Kim et al., 1998). As large firms can raise their funds easily from the capital market and these firms have high bond rating so they do not need to hold more cash as compared to small firms. This negative effect of size on cash holding is similar to the work of (Ferreira \& Vilela, 2004). The study also concluded that the relation between Investment Opportunities and Cash holding is significant and positive, which is similar to that of trade off model of (Ferreira \& Vilela, 2004); those firms having more investment opportunities hold more cash to take advantage of the positive NPV's and to avoid financial distress due to greater bankruptcy cost. The NWC have a significant and positive effect on corporate cash holding of the companies, which is in support with the results of (Ferreira \& Vilela, 2004) and trade off theory. $N W C$ can be used as a substitute of cash, so those firms having more $N W C$ hold less cash. The study shows negative relation between firm structure and cash holding, which recommends that the diversified firms should hold less cash because they can raise their funds easily as compared to focused firms by selling their noncore segments or the accessibility of internal capital markets, which reduces the benefits of holding cash. Due to the positive relationship of growth opportunities with cash holding, it is recommended that those firms having more investment opportunities should hold more cash to take advantage of positive NPV's. We also suggested that large companies have easy excess to capital markets and can raise their funds easily so they need to hold less cash as compared to small firms. The study has some limitations which are needed to be 
improved. The sample size of our study was restricted to 80 firms due to the no availability of diversified firms, so if the sample size is increased different results can be obtained. Moreover, as different industries have different level of cash holding, diversified firms have more than one segment which operates in different industries. And if the effect of industry is controlled by using adjusted cash holding, different results can be obtained.

\section{Acknowledgements}

I would like to thanks an anonymous reviewer for his/her comments.

\section{Conflicts of Interest}

The authors declare no conflicts of interest regarding the publication of this paper.

\section{References}

Al-Najjar, B. (2011). The Inter-Relationship between Capital Structure and Dividend Policy: Empirical Evidence from Jordanian Data. International Review of Applied Economics, 25, 209-224. https://doi.org/10.1080/02692171.2010.483464

Al-Najjar, B., \& Clark, E. (2017). Corporate Governance and Cash Holdings in MENA: Evidence from Internal and External Governance Practices. Research in International Business and Finance, 39, 1-12. https://doi.org/10.1016/j.ribaf.2016.07.030

Bagwell, L. S., \& Zechner, J. (1993). Influence Costs and Capital Structure. Journal of Finance, 48, 975-1008. https://doi.org/10.1111/j.1540-6261.1993.tb04027.x

Baskin, J. (1987). Corporate Liquidity in Games of Monopoly Power. The Review of Economics and Statistics, 69, 312-319. https://doi.org/10.2307/1927239

Bates, T. W., Kahle, K. M., \& Stulz, R. M. (2009). Why Do U.S. Firms Hold So Much More Cash Than They Used to? Journal of Finance, 64, 1985-2021.

Brisker, E. R., Çolak, G., \& Peterson, D. R. (2013). Changes in Cash Holding around the S\&P 500 Additions. Journal of Banking \& Finance, 37, 1787-1807. https://doi.org/10.1016/j.jbankfin.2013.01.021

Drobetz, W., \& Grüninger, M. (2006). Corporate Cash Holdings: Evidence from a Different Institutional Setting (No. 2006/06). WWZ Discussion Paper.

Ferreira, A. M., \& Vilela, A. S. (2004). Why Do Firms Hold Cash? Evidence from EMU Countries. European Financial Management, 10, 295-319. https://doi.org/10.1111/j.1354-7798.2004.00251.x

Khanna, N., \& Tice, S. (2001). The Bright Side of Internal Capital Markets. Journal of Finance, 56, 1489-1528. https://doi.org/10.1111/0022-1082.00377

Kim, C. S., Mauer, D. C., \& Sherman, A. E. (1998). The Determinants of Corporate Liquidity: Theory and Evidence. Journal of Financial and Quantitative Analysis, 33, 335-359. https://doi.org/10.2307/2331099

Kraus, A., \& Litzenberger, R. H. (1973). A State Preference Model of Optimal Financial Leverage. The Journal of Finance, 28, 911-922.

https://doi.org/10.1111/j.1540-6261.1973.tb01415.x

Lamont, O. (1997). Cash Flow and Investment: Evidence from Internal Capital Markets. Journal of Finance, 52, 83-109. https://doi.org/10.1111/j.1540-6261.1997.tb03809.x

Milgrom, P. I., \& Roberts, J. (1990). Bargaining Costs, Influence Costs, and the Organiza- 
tion of Economic Activity. In J. Alt, \& K. Shepsle (Eds.), Perspectives on Positive Political Economy (pp. 143-155). Cambridge: Cambridge University Press.

Mwangi, L. W., Makau, M. S., \& Kosimbei, G. (2014). Relationship between Capital Structure and Performance of Non-Financial Companies Listed in the Nairobi Securities Exchange, Kenya. Global Journal of Contemporary Research in Accounting, Auditing and Business Ethics, 1, 72-90.

Myers, S. C. (1984). The Capital Structure Puzzle. The Journal of Finance, 39, 574-592. https://doi.org/10.1111/j.1540-6261.1984.tb03646.x

Opler, T., Pinkowitz, L., Stulz, R., \& Williamson, R. (1999). The Determinants and Implications of Corporate Cash Holdings. Journal of Financial Economics, 52, 3-46. https://doi.org/10.1016/S0304-405X(99)00003-3

Ozkan, A., \& Ozkan, N. (2004). Corporate Cash Holdings: An Empirical Investigation of UK Companies. Journal of Banking \& Finance, 28, 2103-2134. https://doi.org/10.1016/j.jbankfin.2003.08.003

Pinkowitz, L., \& Williamson, R. (2001). Bank Power and Cash Holdings: Evidence from Japan. The Review of Financial Studies, 14, 1059-1082.

https://doi.org/10.1093/rfs/14.4.1059

Rajan, R., Servaes, H., \& Zingales, L. (2000). The Cost of Diversity: The Diversification Discount and Inefficient Investment. Journal of Finance, 55, 35-80. https://doi.org/10.1111/0022-1082.00200

Shin, H., \& Stulz, R. (1998). Are Internal Capital Markets Efficient? Quarterly Journal of Economics, 113, 531-553.

Shleifer, A., \& Vishny, R. W. (1992). Liquidation Values and Debt Capacity: A Market Equilibrium Approach. The Journal of Finance, 47, 1343-1366. https://doi.org/10.1111/j.1540-6261.1992.tb04661.x

Stowe, J. D., \& Xing, X. (2006). Can Growth Opportunities Explain the Diversification Discount? Journal of Corporate Finance, 12, 783-796.

Subramaniam, V., Tang, T. T., Yue, H., \& Zhou, X. (2011). Firm Structure and Corporate Cash Holdings. Journal of Corporate Finance, 17, 759-773.

https://doi.org/10.1016/j.jcorpfin.2010.06.002 